\title{
PENGARUH EDUKASI DENGAN METODE PEER GROUP TERHADAP PERUBAHAN PENGETAHUAN, SIKAP DAN TEKANAN DARAH PADA LANSIA DI UPTD PUSKESMAS SUKAHAJI KABUPATEN MAJALENGKA
}

\author{
Tresna Komalasari ${ }^{1}$, Tria Astika Endah Permatasari ${ }^{2}$ dan Nana Supriyatna ${ }^{3}$ \\ Fakultas Ilmu Keperawatan Universitas Muhammadiyah Jakarta ${ }^{1,3}$ \\ Fakultas Kedokteran dan Kesehatan Universitas Muhammadiyah Jakarta ${ }^{2}$ \\ Email: tresnakomalasari16@gmail.com, astika.tria@gmail.com dan \\ nanaumj@gmail.com
}

\begin{abstract}
This study aims to influence the education of peer group methods on changes in knowledge, attitudes and blood pressure in the elderly at UPTD Puskesmas Sukahaji, Majalengka Regency. This type of research used in this study is quasy experimental research (quasi-experimental) with one group pretest-posttest design. The number of samples in this study were 60 elderly in UPTD Puskesmas Sukahaji, Majalengka Regency. When this research was conducted in January-June 2019. The results showed that blood pressure before the implementation of education obtained an average of 167.1 and after the implementation of education obtained an average of 162.3. Knowledge before the implementation of education obtained an average of 64.7 and after the implementation of education obtained an average of 76.8. The average attitude before the implementation of education is 75.8 and the attitude after the implementation of education is obtained on average by 83.9. There is an influence of education by the peer group method to change the knowledge of the elderly in UPTD Puskesmas Sukahaji, Majalengka Regency. There is an influence of education with peer group methods on the changing attitudes of the elderly in UPTD Puskesmas Sukahaji, Majalengka Regency. There is an effect of education with peer group methods on changes in elderly blood pressure in UPTD Puskesmas Sukahaji, Majalengka Regency. The UPTD Puskesmas Sukahaji can implement peer group education on hypertension to increase knowledge and build a positive attitude so that the elderly can play an active role in efforts to improve the health status of the elderly, especially to prevent hypertension.
\end{abstract}

Keywords: Education, Peer group, Knowledge, Attitude, Hypertension dan Ederly

\footnotetext{
Abstrak

Penelitian ini bertujuan untuk pengaruh edukasi dengan metode peer group terhadap perubahan pengetahuan, sikap dan tekanan darah pada lansia di UPTD Puskesmas Sukahaji Kabupaten Majalengka. Jenis penelitian yang digunakan pada penelitian ini adalah penelitian quasy eksperiment (eksperimen semu) dengan desain one group pretest-posttest design. Jumlah sampel pada penelitian ini adalah 60 lansia di UPTD Puskesmas Sukahaji Kabupaten Majalengka. Waktu penelitian ini memerlukan waktu dilaksanakan pada bulan Januari-Juni 2019. Hasil penelitian
} 
menunjukkan bahwa tekanan darah sebelum pelaksanaan edukasi diperoleh ratarata sebesar 167.1 dan sesudah pelaksanaan edukasi diperoleh rata-rata sebesar 162.3. Pengetahuan sebelum pelaksanaan edukasi diperoleh rata-rata sebesar 64.7 dan setelah pelaksanaan edukasi diperoleh rata-rata sebesar 76.8. Rata-rata sikap sebelum pelaksanaan edukasi sebesar 75.8 dan sikap setelah pelaksanaan edukasi diperoleh rata-rata sebesar 83.9. Ada pengaruh edukasi dengan metode peer group terhadap perubahan pengetahuan lansia di UPTD Puskesmas Sukahaji Kabupaten Majalengka. Ada pengaruh edukasi dengan metode peer group terhadap perubahan sikap lansia di UPTD Puskesmas Sukahaji Kabupaten Majalengka. Ada pengaruh edukasi dengan metode peer group terhadap perubahan tekanan darah lansia di UPTD Puskesmas Sukahaji Kabupaten Majalengka. Pihak UPTD Puskesmas Sukahaji dapat menerapkan edukasi dengan metode peer group tentang hipertensi untuk meningkatkan pengetahuan dan membangun sikap yang positif agar lansia berperan aktif dalam upaya peningkatan derajat kesehatan pada lansis khususnya untuk mencegah penyakit hipertensi.

Kata kunci: Edukasi, Peer Group, Pengetahuan, Sikap, Hipertensi, Lansia

\section{Pendahuluan}

Pengaruh era globalisasi dalam berbagai bidang, perkembangan teknologi dan industri mengakibatkan perubahan pada perilaku dan gaya hidup masyarakat serta situasi lingkungan. Hal ini dapat dilihat dari adanya perubahan pola konsumsi makanan yang serba instan, serta perkembangan dunia teknologi dan komunikasi yang semakin meninggi membuat manusia seakan enggan untuk bergerak dan berolahraga (Subandi, 2017). Kondisi ini juga berpengaruh terhadap munculnya berbagai masalah pada lansia yang ada kaitannya dengan aspek medis, ekonomi, psikologis juga sosial yang menuntut perlunya peningkatan pelayanan kesehatan pada lanjut usia. Intervensi kesehatan tersebut tepat diberikan sejak periode sebelumnya yaitu mulai 1000 Hari Pertama Kehidupan hingga dewasa. Intervensi yang tepat pada setiap siklus kehidupan merupakan kunci lansia yang sehat, produktif dan mandiri (Kemenkes, 2017).

Status gizi lansia dimulai sejak awal kehidupan, yaitu mulai dari sejak periode kehamilan. Pertumbuhan janin yang optimal dilanjutkan dengan pemberian ASI eksklusif dan kecukupan gizi pada masa bayi dan balita menentukan kesehatan pada masa selanjutnya, dimana intensi dan peran ibu dalam memberikan gizi berdampak terhadap status gizi balita, dan selanjutnya secara berkesinambungan menentukan status gizi dan kesehatan pada periode selanjutnya (Permatasari dan Syafruddin, 2016; Permatasari, et al., 2018; Permatasari dan Chadirin, 2020). Penerapan gizi seimbang untuk mencegah terjadinya berbagai masalah gizi dan kesehatan terutama penyakit yang umum terjadi pada lansia seperti osteoporosis dan hipertensi perlu dilakukan. (Permatasari, 2011; Permatasari 2016). Selain itu, imunitas tubuh yang terbentuk sejak periode awal kehidupan dan terkait dengan berbagai penyakit infeksi seperti Tubercullosis memengaruhi kesehatan lansia ((Ginanjar, Permatasari, Supriyatna, 2019; Pendit, Permatasari, Supriyatna, 2019). Oleh karena itu, upaya pembinaan terhadap mengenai faktor risiko yang harus dihindari dan faktor protektif yang dapat dilakukan 
untuk mencegah hipertensi menjadi priotitas dalam peningkatan kesehatan lansia (Kemenkes, 2017).

Laporan United Nations tahun 2017, mencatat jumlah penduduk yang berusia 60 tahun atau lebih atau lansia pada tahun 2017 berjumlah 962 juta. Jumlah ini dua kali lebih besar dibanding tahun 1980, yaitu sebanyak 382 juta. Diprediksikan pada tahun 2050, jumlah lansia diperkirakan akan berlipat ganda mencapai hampir 2,1 miliar dan sebesar $79 \%$ populasi dunia yang berusia 60 atau lebih akan tinggal di daerah berkembang. Peningkatan jumlah lansia paling tinggi terjadi di Afrika, di mana populasi lansia meningkat lebih dari tiga kali lipat antara tahun 2017 hingga tahun 2050, dari 69 menjadi 226 juta. Kemudian diikuti oleh Amerika Latin dan Karibia, meningkat lebih dari dua kali lipat antara 2017 dan 2050, dari 76 menjadi 198 juta. Asia juga diperkirakan akan mengalami peningkatan lansia dua kali lipat, yang diproyeksikan meningkat dari 549 juta pada 2017 menjadi hampir 1,3 miliar pada 2050 (Nations, 2017).

Pengertian lansia atau lanjut usia yaitu seseorang yang sudah mencapai usia 60 tahun atau lebih (UU Nomor 13 Tahun 1998 tentang Kesejahteraan Lanjut Usia). Dengan bertambahnya umur, fungsi fisiologis mengalami penurunan akibat proses penuaan sehingga penyakit tidak menular banyak muncul pada lanjut usia (Kementerian Kesehatan RI, 2016). Proses penuaan merupakan proses yang mengakibatkan perubahan-perubahan meliputi fisik, fisiologis dan psikososial. Pada perubahan fisiologis terjadi penurunan sistem kekebalan tubuh dalam menghadapi gangguan dari dalam maupun luar tubuh. Salah satu gangguan kesehatan yang paling banyak dialami oleh lansia adalah pada sistem kardiovaskuler (Organization 2016).

World Health Organization (WHO) pada tahun 2016, melaporkan bahwa secara global penyakit kardiovaskuler menyebabkan 17 juta kematian pertahun. Dari jumlah tersebut 9,4 juta diantaranya disebabkan oleh komplikasi hipertensi. Hipertensi menyebabkan setidaknya $45 \%$ kematian akibat penyakit jantung dan $51 \%$ kematian akibat stroke (Organization 2016). Di Indonesia, hasil Riset Kesehatan Dasar (Riskesdas) tahun 2018 menunjukkan bahwa prevalensi hipertensi di Indonesia sebesar 34,1\%, meningkat dibanding hasil riskesdas tauhn 2016 sebesar 25,8\%. Berdasarkan Riskesdas 2018, Provinsi dengan prevalensi hipertensi tertinggi terdapat di Provinsi Kalimantan Selatan sebesar 44,1\% dan terendar Papua sebesar 22,2\%. Sedangkan Provinsi Jawa Barat sebesar kedua tertinggi setelah Kalimantan Selatan yaitu sebesar 42,8\% (Kementerian Kesehatan RI, 2018).

Jumlah penduduk di Kabupaten Majalengka pada tahun 2017 dengan kategori lansia sebanyak 181.020 orang. Jumlah tersebut terbagi ke dalam kelompok pra lansia (45-59 tahun) sebanyak 71.847 orang, lansia usia 60-64 tahun sebanyak 48.349 orang, lansia usia 65-69 tahun sebanyak 35.403 orang dan lansia usia > 70 tahun sebanyak 25.421 orang. Adapun jumlah penduduk lansia pada tahun 2017 yang mengalami hipertensi diketahui sebanyak 137.857 orang $(76,15 \%)$.

Salah satu puskesmas dengan jumlah penduduk hipertensi paling banyak di Kabupaten Majalengka terdapat di UPTD Puskesmas Sukahaji yaitu sebanyak 1.184 
orang. Adapun penelitian ini dilakukan di Posbindu di UPTD Puskesmas Sukahaji dikarenakan lansianya aktif mengikuti kegiatan di Posbindu yang terletak di 3 desa yaitu Desa Cikeusik, Desa Jayi dan Desa Padahanten. Prevalensi kejadian hipertensi di UPTD Puskesmas Sukahaji pada lansia pada tahun 2018 yaitu sebesar 59,6\%, prevalensi ini mengalami sedikit penurunan dibanding tahun 2017 yaitu sebesar 60,5\% . Gaya hidup lansia di UPTD Puskesmas Sukahaji merupakan faktor yang berperan penting terhadap kejadian beberapa penyakit kronik seperti hipertensi. Perubahan gaya hidup ini tidak lepas dari bergesernya kebiasaan masyarakat dalam kehidupan seharihari di perkotaan, kecenderungan untuk melakukan aktifitas fisik, kebiasaan merokok, mengkonsumsi makanan siap saji sudah sangat tinggi. Hal ini dapat berpengaruh terhadap sistem kardiovaskuler sehingga dapat menyebabkan penyakit hipertensi.

Salah satu upaya penanganan pada hipertensi dengan non farmakologis yaitu dengan metode peer group. Dukungan kelompok sesama penderita atau peer group dapat merubah respon psikologis maladaptif menjadi respon psikologis yang adaptif. Di negara maju, peer group diterapkan sebagai salah satu bentuk terapi pada sekelompok penderita. Metode ini dilakukan oleh Maria (2014) dan menunjukkan bahwa dapat membantu pasien hipertensi dan hasil penelitiannya bahwa dengan memberikan perlakuan peer group, dapat meningkatkan kepatuhan pasien hipertensi terhadap manajemen gaya hidup dan penggunaan obat. Perubahan perilaku ini akan berdampak pada penurunan tekanan darah karena terjadi perubahan gaya hidup pada pasien hipertensi tersebut (Maria 2014).

Hasil penelitian lainnya juga menunjukkan bahwa perlakuan peer group atau kelompok sebaya ternnyata dapat mengubah respons psikologis maladaptif menjadi respons psikologis adaptif pada wanita yang menderita kanker payudara, hal ini berarti bahwa dengan perlakuan peer group akan merubah kondisi psikologis seseorang dan dampaknya diantaranya dapat merubah psikologis maladaptrif menjadi adaptif. Berdasarkan hal tersebut maka penulis tertarik untuk melakukan penelitian tentang Pengaruh Edukasi dengan Metode Peer Group Terhadap Perubahan Pengetahuan, Sikap dan Tekanan Darah Pada Lansia di Uptd Puskesmas Sukahaji Kabupaten Majalengka. (Ilkafah 2016)

\section{Metode Penelitian}

Jenis penelitian yang digunakan pada penelitian ini adalah penelitian quasy eksperiment (eksperimen semu) dengan desain one group pretest-posttest design. Sampel dalam penelitian ini adalah seluruh lansia yang aktif berkunjung ke Posbindu di wilayah UPTD Puskesmas Sukahaji Kabupaten Majalengka sebanyak 60 orang. Proses edukasi dilakukan sebanyak 1 minggu 1 kali sebanyak 3 kali di tiga posbindu dengan jumlah responden sebanyak 60 orang. Pengumpulan data dilakukan dua kali yaitu sebelum dilaksanakan edukasi (pretest) dan sesudah dilaksanakan edukasi (postest) dan waktu pengumpulan data dilaksanakan mulai tanggal 8 Mei 2019 sampai dengan 28 Mei 2019. Analisis univariat menggunakan distribusi frekuensi dan analisis bivariat menggunakan uji t berpasangan. Analisis ini digunakan untuk melihat perbedaan pretest 
dengan posttest pada kelompok intervensi. Pada analisis ini digunakan uji beda 2 mean dependen.

\section{Hasil dan Pembahasan}

\section{A. Hasil Penelitian}

\section{Uji Normalitas}

Tabel 1

Hasil Uji Normalitas Pengetahuan, Sikap dan Tekanan Darah Sebelum dan Sesudah Edukasi dengan Kolmogorv Sminorv test

\begin{tabular}{lccc}
\hline \multirow{2}{*}{ Variabel } & \multicolumn{3}{c}{ Kolmogorov } \\
& Statistic & Smirnov & Sig. \\
\cline { 3 - 3 } & & Df & \\
\hline Pengetahuan (pretest) & 0.082 & 60 & 0.200 \\
\hline Pengetahuan (postest) & 0.093 & 60 & 0.200 \\
\hline Sikap (pretest) & 0.080 & 60 & 0.200 \\
\hline Sikap (Postest) & 0.092 & 60 & 0.200 \\
\hline TD Sistole (pretest) & .173 & 60 & .060 \\
\hline TD Diastole (pretest) & .264 & 60 & .070 \\
\hline TD Sistole (postest) & .153 & 60 & .081 \\
\hline TD Diastole (postest) & .241 & 60 & .090 \\
\hline
\end{tabular}

Berdasarkan hasil uji normalitas, menunjukkan bahwa data pengetahuan dan sikap baik sebelum dan sesudah edukasi menghasilkan $p$ value masing-masing sebesar 0,200. Hal ini berarti $p$ value kedua data yang diuji $>0,05$ sehingga pengetahuan dan sikap sebelum dan sesudah edukasi dinyatakan berdistribusi normal dan dapat dilanjutkan dengan uji $t$ berpasangan untuk mengetahui pengaruh edukasi dengan metode peer group terhadap perubahan pengetahuan lansia. Sedangkan data tekanan darah sebelum edukasi menghasilkan $p$ value masing-masing sebesar 0,060 (sistole) dan 0,070 (diastole). Sedangkan tekanan darah sesudah edukasi menghasilkan p value masing-masing sebesar 0,081 (sistole) dan 0,090 (diastole). Hal ini berarti $p$ value data yang diuji $>0,05$ sehingga tekanan darah sebelum dan sesudah edukasi dinyatakan berdistribusi normal dan dapat dilanjutkan dengan uji t berpasangan untuk mengetahui pengaruh edukasi dengan metode peer group terhadap tekanan darah lansia.

\section{Analisis Univariat}

a. Gambaran Pengetahuan Lansia Sebelum dan Sesudah Edukasi dengan Metode Peer Group 


\section{Tabel 2}

Distribusi Frekuensi Pengetahuan dan Sikap Lansia Sebelum dan Sesudah Edukasi dengan Metode Peer Group

\begin{tabular}{cccccc}
\hline Variabeel & Pengukuran & Mean & Min-Max & SD & 95\% CI \\
\hline Pengetahuan & Pretest & 64.7 & $31.6-94.7$ & 14.636 & $60.9-68.5$ \\
\cline { 2 - 6 } Lansia & Postest & 76.8 & $36.8-100$ & 13.701 & $73.2-80.3$ \\
\hline \multirow{2}{*}{ Sikap Lansia } & Pretest & 75.8 & $58.3-90.7$ & 8.200 & $73.6-77.9$ \\
\cline { 2 - 6 } & Postest & 83.9 & $63.0-94.4$ & 7.007 & $82.1-85.7$ \\
\hline
\end{tabular}

Berdasarkan tabel 2, menunjukkan bahwa pengetahuan sebelum pelaksanaan edukasi diperoleh rata-rata sebesar 64.7. Berdasarkan nilai 95\% CI sebesar 60.9-68.5, yang artinya bahwa 95\% diyakini pengetahuan lansia sebelum edukasi dengan metode peer group berada pada level 60.9-68.5. Adapun pengetahuan setelah pelaksanaan edukasi diperoleh rata-rata sebesar 76.8. Berdasarkan nilai 95\% CI sebesar 73.2-80.3, yang artinya bahwa 95\% diyakini pengetahuan lansia sesudah edukasi dengan metode peer group berada pada level 73.2-80.3. Sementara sikap sebelum pelaksanaan edukasi diperoleh rata-rata sebesar 75.8. Berdasarkan nilai 95\% CI sebesar 73.6-77.9 yang artinya bahwa 95\% diyakini sikap lansia sebelum edukasi dengan metode peer group di berada pada level 73.6-77.9. Adapun sikap setelah pelaksanaan edukasi diperoleh rata-rata sebesar 83.9. Berdasarkan nilai 95\% CI sebesar 82.1-85.7, yang artinya bahwa 95\% diyakini sikap lansia sesudah edukasi dengan metode peer group berada pada level 82.1-85.7.

b. Gambaran Tekanan Darah Lansia Sebelum dan Sesudah Edukasi dengan Metode Peer Group

Tabel 3

Distribusi Frekuensi Tekanan Darah Lansia Sebelum Edukasi dengan Metode Peer Group

\begin{tabular}{|c|c|c|c|c|}
\hline $\begin{array}{c}\text { Tekanan } \\
\text { Darah Lansia }\end{array}$ & Pengukuran & $\begin{array}{c}\text { Mean } \\
\text { (Rata- rata) }\end{array}$ & $\begin{array}{c}\text { Minimun } \\
\text { Maksimum }\end{array}$ & S.D \\
\hline \multirow[b]{2}{*}{ Pretest } & Sistole & 167,1 & $150-190$ & 12.086 \\
\hline & Diastole & 167,1 & $90-120$ & 8.401 \\
\hline \multirow[b]{2}{*}{ Postest } & Sistole & 162,3 & $140-190$ & 13.195 \\
\hline & Diastole & 97.8 & $90-120$ & 7.831 \\
\hline
\end{tabular}

Berdasarkan tabel 3, menunjukkan bahwa tekanan darah sistole sebelum pelaksanaan edukasi diperoleh rata-rata sebesar 167.1 dengan nilai paling rendah adalah 150 dan paling tinggi 190 serta nilai standar deviasinya sebesar 12.086. Sedangkan tekanan darah diastole sebelum pelaksanaan edukasi diperoleh rata-rata sebesar 106.5 dengan nilai paling rendah adalah 90 dan paling tinggi 120 serta nilai standar deviasinya sebesar 8.401. Tekanan darah sistole sesudah pelaksanaan edukasi diperoleh rata-rata sebesar 162.3 dengan nilai paling rendah adalah 140 dan paling tinggi 190 
serta nilai standar deviasinya sebesar 13.195. Sedangkan tekanan darah diastole sesudah pelaksanaan edukasi diperoleh rata-rata ssebesar 97.8 dengan nilai paling rendah adalah 90 dan paling tinggi 120 serta nilai standar deviasinya sebesar 7.831.

Tabel 4

Distribusi Frekuensi Berdasarkan Jenis Kelamin dan Usia Responden

\begin{tabular}{llcc}
\hline No & \multicolumn{1}{c}{ Variabel } & F & \% \\
\hline 1 & Laki-laki & 18 & 30.0 \\
2 & Perempuan & 42 & 70.0 \\
\hline 1 & < rata-rata (64,2 tahun) & 35 & 58.3 \\
2 & > rata-rata (64,2 tahun) & 25 & 41.7 \\
\hline
\end{tabular}

Berdasarkan tabel 4, menunjukkan bahwa sebagian besar responden di UPTD Puskesmas Sukahaji Kabupaten Majalengka berjenis kelamin perempuan (70\%) dan sebagian besar responden di UPTD Puskesmas Sukahaji Kabupaten Majalengka berusia < rata-rata (65 tahun).

3. Analisis Bivariat

\section{Tabel 5}

Pengaruh Edukasi dengan Metode Peer Group Terhadap Perubahan Pengetahuan Lansia

\begin{tabular}{llcccc}
\hline \multicolumn{2}{c}{ Variabel } & N & Mean & Std. Dev. & p value \\
\hline \multirow{2}{*}{$\begin{array}{l}\text { Pengetahuan } \\
\text { Lansia }\end{array}$} & Pretest & 60 & 64.73 & 14.63 & 0.000 \\
\cline { 2 - 5 } & Postest & 60 & 76.83 & 13.70 & \\
\multirow{2}{*}{ Sikap Lansia } & Pretest & 60 & 75.8 & 8.200 & \multirow{2}{*}{0.000} \\
\cline { 2 - 6 } & Postest & 60 & 83.9 & 7.007 & \\
\hline
\end{tabular}

Berdasarkan tabel 5, menunjukkan bahwa secara statistik menunjukkan adanya perbedaan yang bermakna, dari hasil uji statistik diperoleh $p$ value = 0,000 yang berarti $p$ value $<\alpha(0,05)$ sehingga hipotesis nol ditolak. Sehingga edukasi dengan metode peer group berpengaruh terhadap perubahan pengetahuan dan sikap lansia di UPTD Puskesmas Sukahaji Kabupaten Majalengka

Tabel 6

Pengaruh Edukasi dengan Metode Peer Group Terhadap Perubahan Tekanan Darah Lansia di UPTD Puskesmas Sukahaji Kabupaten Majalengka

\begin{tabular}{cccccc}
\hline \multicolumn{2}{c}{$\begin{array}{c}\text { Tekanan Darah } \\
\text { Lansia }\end{array}$} & N & Mean & Std. Dev. & p value \\
\cline { 2 - 5 } & Pretest & 60 & 167.1 & 12.086 & \\
\cline { 2 - 5 } Sistole & Postest & 60 & 162.3 & 13.195 & 0,000 \\
\hline \multirow{2}{*}{ Diastole } & Pretest & 60 & 106.5 & 8.401 & \\
\cline { 2 - 5 } & Postest & 60 & 97.8 & 7.831 & 0,000 \\
\hline
\end{tabular}


Berdasarkan tabel 6, menunjukkan bahwa secara statistik dengan uji $\mathrm{t}$ berpasangan, diperoleh value $=0,000$ yang berarti $\mathrm{p}$ value $<\alpha(0,05)$ sehingga hipotesis nol ditolak. Dengan demikian maka secara statistik bahwa edukasi dengan metode peer group berpengaruh terhadap perubahan tekanan darah lansia (sistole dan diastole) di UPTD Puskesmas Sukahaji Kabupaten Majalengka.

\section{B. Pembahasan}

Berdasarkan hasil penelitian menunjukkan bahwa edukasi dengan metode peer group berpengaruh terhadap perubahan pengetahuan lansia di UPTD Puskesmas Sukahaji Kabupaten Majalengka. Hasil penelitian ini sejalan dengan teori (Ridwan Maulana, Opdenakker, and Bosker 2014) melalui edukasi dapat menjembatani kesenjangan antara pengetahuan, sikap dan tingkah laku kesehatan dan pendidikan kesehatan memotivasi seseorang untuk menerima informasi kesehatan serta berbuat sesuai dengan informasi tersebut agar mereka menjadi lebih tahu dan bersikap lebih positif.

Menurut (Liliweri 2014) bahwa edukasi dilaksanakan dapat mengembangkan pesan maupun memilih media yang lebih tepat sehingga informasi yang diterima dapat dimengerti. Melalui edukasi tidak hanya merubah seseorang menjadi tahu dari tidak tahu tetapi lebih pada merubah suatu prinsip yang sebelumnya tidak diketahui benar atau salah. Sehingga memberikan keyakinan lebih kekal pengetahuannya.

Berdasarkan hasil penelitian menunjukkan bahwa edukasi dengan metode peer group berpengaruh terhadap perubahan sikap lansia di UPTD Puskesmas Sukahaji Kabupaten Majalengka. Hasil penelitian ini sejalan dengan teori Mozes (2015), melalui penyebaran edukasi terbukti efektif dalam meningkatkan pengetahuan serta mempengaruhi sikap. Sedangkan menurut (Imron 2015) bahwa edukasi atan dapat menghasilkan perubahan perilaku pada individu dengan cara memodifikasi pengetahuan, sikap, keyakinan, atau perilaku seseorang.

Sikap seseorang tidak dapat berubah begitu saja tanpa ada proses yang mendasarinya. Melalui edukasi akan terjadi proses perubahan cara berfikir seseorang karena terjadi dialog atau diskusi terbuka untukmengeluarkan pendapatnya masingmasing. Menurut (Ridwan Maulana, Opdenakker, and Bosker 2014) bahwa sikap merupakan perbuatan yang didasari oleh keyakinan berdasarkan norma-norma yang ada di masyarakat dan biasanya norma agama. Namun demikian perbuatan yang akan dilakukan manusia biasanya tergantung pada apa permasalahannya serta benarbenar berdasarkan keyakinan atau kepercayaannya masing-masing.

Berdasarkan hasil penelitian menunjukkan bahwa edukasi dengan metode peer group berpengaruh terhadap perubahan tekanan darah lansia di UPTD Puskesmas Sukahaji Kabupaten Majalengka. Hasil penelitian ini sejalan dengan penelitian Yoani (Aty 2014) yang menyatakan bahwa dukungan kelompok sebaya adalah salah satu metode promosi kesehatan yang efektif dalam meningkatkan perilaku hidup sehat dan menekan rasa sakit. 
Peer group adalah sekelompok individu pada usia relatif sama, yang merupakan kelompok sosial yang mengatur langkah untuk bersosialisasi. Pada banyak remaja, bagaimana mereka dipandang oleh teman sebaya merupakan aspek yang terpenting dalam kehidupan mereka (Santrock 2003).

Menurut Sunarto, pengertian peer group adalah teman bermain yang terdiri atas kerabat untuk belajar nilai-nilai. Sedangkan menurut Riyanti, Peer group adalah salah satu ciri perilaku social dimana perilaku kelompok tersebut dapat mempengaruhi perilaku serta nilai individu yang menjadi anggotanya dan nilai yang baru yang gilirannya akan menggantikan nilai dan perilaku sebelumnya.

Ciri-ciri mendasar peer group adalah jumlah anggota relatif kecil, adanya kepentingan yang bersifat umum dan dibagi secara langsung, terjadi kerja sama dalam suatu kepentingan yang diharapkan, adanya pengertian pribadi, serta saling hubungan yang tinggi antar anggota dalam kelompok (Rifal Maulana 2015). Berbagai penelitian sebelumnya juga menunjukkan bahwa metode ini juga secara signifikan tidak hanya mampu meningkatkan pengetahuan, sikap, perilaku ataupun keterampilan responden yang diberikan intervensi dengan metode peer group, namun juga mampu memberikan kepuasan sehingga mudah untuk diterima dan diterapkan oleh responden (Syafruddin dan Permatasari, 2015; Syafruddin, dan Permatasari, 2016). Metode ini bersifat interaktif dan menyenangkan bagi lansia sehingga dapat mengurangi stress yang berperan dalam pencegahan hipertensi.

Berdasarkan hasil penelitian ini maka edukasi dengan metode peer group mempunyai dampai yang positif terhadap perubahan tekanan darah lansia di UPTD Puskesmas Sukahaji Kabupaten Majalengka. Maka dari itu edukasi dengan metode peer group dapat dijadikan sebagai alternatif bagi petugas kesehatan untuk meningkatkan kesadaran dan tindakan lansia dalam mengontrol tekanan darah dan mencegah komplikasi akibat hipertensi yang lebih parah.

\section{Kesimpulan}

Tekanan darah sebelum pelaksanaan edukasi diperoleh rata-rata sebesar 167.1 dan sesudah pelaksanaan edukasi diperoleh rata-rata sebesar 162.3 yang berarti telah terjadi sedikit penurunan tekanan darah pada lansia di lokasi penelitian setelah dilaksanakan 3x edukasi dengan metode peer group sebesar 4,8.

Pengetahuan sebelum pelaksanaan edukasi diperoleh rata-rata sebesar 64.7 dan setelah pelaksanaan edukasi diperoleh rata-rata sebesar 76.8 sehingga telah terjadi peningkatan pengetahuan setelah dilaksanakan 3x edukasi dengan metode peer group sebesar 21,1. Rata-rata sikap sebelum pelaksanaan edukasi sebesar 75.8 dan sikap setelah pelaksanaan edukasi diperoleh rata-rata sebesar 83.9 sehingga telah terjadi peningkatan sikap setelah dilaksanakan 3x edukasi dengan metode peer group sebesar 8.1 .

Ada pengaruh edukasi dengan metode peer group terhadap perubahan pengetahuan lansia di UPTD Puskesmas Sukahaji Kabupaten Majalengka. Ada pengaruh edukasi dengan metode peer group terhadap perubahan sikap lansia di UPTD 
Puskesmas Sukahaji Kabupaten Majalengka. Ada pengaruh edukasi dengan metode peer group terhadap perubahan tekanan darah lansia di UPTD Puskesmas Sukahaji Kabupaten Majalengka. 


\section{BIBLIOGRAFI}

Aty, Yoani Maria Vianney Bita. (2014). The Influence of Peer Group Support on the Compliance of Life-style Management and Drug Taking in Mild Hypertensive Patients Using Pre-experiment Health Promotion Model in Community Health Center, Ruteng. Jurnal Info Kesehatan, 12(1), 566-584.

Ginanjar, Y., Permatasari, TAE., Supriyatna, N. (2019). Analisis Pengaruh Psikososial dan Faktor Resiko Lainya Terhadap Kejadian TB MDR. Bina Generasi: Jurnal Kesehatan. Vol. 11 (1), p. 46-54. https://ejurnal.biges.ac.id/index.php/kesehatan/article/view/134/79.

Ilkafah, Ilkafah. (2016). The Effect of Peer Group Support to Psychological Response of Patient With Breast Cancer: A Quasy Experiment. Indonesian Contemporary Nursing Journal, 1(1), 24-30.

Imron, Ali. (2015). Hukum Perkawinan Islam di Indonesia. Semarang: CV. Karya Abadi Jaya.

Kemenkes, R. I. (2017). Profil kesehatan Republik Indonesia tahun 2017. Kementerian Kesehatan RI. Jakarta.

Kementrian kesehatan RI. (2018). Hasil utama riskesdas 2018. 61. https://doi.org/1 Desember 2013

Liliweri, Alo. (2014). Sosiologi dan komunikasi organisasi. Jakarta: Bumi Aksara.

Maria. (2014). The Influence Of Peer Group Support On The Compliance Of Life-Style Management And Drug Taking In Mild Hypertensive Patients Using PreExperiment Health Promotion Model In Community Health Center,Ruteng . Jurnal Info Kesehatan, Vol. 12, N.

Maulana, Ridwan, Opdenakker, Marie-Christine, \& Bosker, Roel. (2014). Teacherstudent interpersonal relationships do change and affect academic motivation: A multilevel growth curve modelling. British Journal of Educational Psychology, 84(3), 459-482.

Maulana, Rifal. (2015). Pengaruh Konsep Diri terhadap Keberhasilan Belajar Mahasiswa Pai Fakultas Tarbiyah dan Keguruan UIN Alauddin Makassar. Universitas Islam Negeri Alauddin Makassar.

Nations, United. (2017). World population prospects: the 2017 revision, key findings and advance tables. United Nations, New York.

Organization, World Health. (2016). World health statistics 2016: monitoring health for the SDGs sustainable development goals. World Health Organization.

Pendit, SA., Permatasari, TAE., Supriyatna N. (2019). Analisis Pengaruh Dukungan Keluarga, dan Faktor Lainnya Terhadap Pemberian Imunisasi MR pada Balita. 
Jurnal Keperawatan Silampari. Volume 3(1),p. 322-331.. DOI: https://doi.org/10.31539/jks.v3i1.848.

https://journal.ipm2kpe.or.id/index.php/JKS/article/view/848

Santrock, John W. (2003). Adolescence perkembangan remaja. Jakarta: Erlangga, $422-424$.

Subandi, Endang. (2017). Pengaruh Senam Diabetes Perhadap Penurunan Kadar Gula Darah Pada Pasien Diabetes Mellitus Di Upt Puskesmas Mundu Kabupaten Cirebon Tahun 2017. Syntax Literate; Jurnal Ilmiah Indonesia, 2(7), 53-68.

Syafruddin, A., Permatasari, TAE. (2015). The Effectiveness of Peer Learning Method in Developing Logical Clinical Skills on Medical Students. Journal of Health, Medicine and Nursing. Vol.17.p.113-117. https://iiste.org/Journals/index.php/JHMN/article/view/25387/26010

Syafruddin A., Permatasari, TAE. (2016). Peer Learning Methode Effectively Improve The Logical Clinical Skills And Student Satisfaction Among Medical Student: A Mix Methode Study. Proceedings of The $2^{\text {nd }}$ International Multidisciplinary Conference, Universitas Muhammadiyah Jakarta. Vol.1(1). p.520-525. https://jurnal.umj.ac.id/index.php/IMC/article/view/1239/1115

Permatasari, TAE. (2011). Hubungan Asupan Kalsium dan Faktor Risiko Lainnya dengan Kejadian Osteoporisis pada Kelompok Dewasa Awal di Wilayah CiputatTangerang Selatan. Jurnal Kedokteran dan Kesehatan Vol.7(2). p.100-111.

Permatasari, TAE. (2016). Balance Diet Practices Related to Nutritional Status Among Elderly In South Tangerang, Indonesia. Proceedings of The $2^{\text {nd }}$ International Multidisciplinary Conference, Universitas Muhammadiyah Jakarta. $\quad$ Vol.1(1).p.757-763. https://jurnal.umj.ac.id/index.php/IMC/article/view/1267/1141

Permatasari, TAE., Syafruddin, A. (2016). Early Initiation ff Breastfeeding Related to Exclusive Breastfeeding and Breastfeeding Duration in Rural and Urban Areas in Subang, West Java, Indonesia. Journal of Health Research, 30(5), p.337-45. DOI: 10.14456/jhr.2016.46.http://www.jhealthres.org/upload/journal/915/30\%285\%29_ tria_p337-345.pdf (doi: 10.14456/jhr.2016.46)

Permatasari, TAE., Sartika, RAD., Achadi EL., et al. (2018). Exclusive Breastfeeding Intention among Pregnant Women. Kesmas: National Public Health Journal. Vol. 12(3), p.134-141. DOI:10.21109/kesmas.v12i3.1446. http://journal.fkm.ui.ac.id/kesmas/article/view/1446/685 
Tresna Komalasari, Tria Astika Endah Permatasari dan Nana Supriyatna

Permatasari, TAE., Chadirin, Y. (2020). Sweetened Condensed Consumption of More than 1 Glass Per Day has an Impact on Underweight among Children Under Age Five. Proceedings of The 4th International Symposium On Health Research (ISHR 2019): series Advances in Health Science Reseacrh. Vol 22. p.615-619. DOI: https://doi.org/10.2991/ahsr.k.200215.120. https://www.atlantispress.com/proceedings/ishr-19/125935054 